Maurice A. Deane School of Law at Hofstra University Scholarly Commons at Hofstra Law

Hofstra Law Student Works

$7-2016$

\title{
Black and Blue Bloods: Protecting Police Officer Families from Domestic Violence
}

Rafaqat Cheema

Maurice A. Deane School of Law at Hofstra University

Follow this and additional works at: http://scholarlycommons.law.hofstra.edu/

hofstra_law_student_works

Part of the Family Law Commons

\section{Recommended Citation}

Family Court Review, 54(3): 487-500, 2016

This Article is brought to you for free and open access by Scholarly Commons at Hofstra Law. It has been accepted for inclusion in Hofstra Law Student Works by an authorized administrator of Scholarly Commons at Hofstra Law. For more information, please contact lawcls@hofstra.edu. 


\title{
BLACK AND BLUE BLOODS: PROTECTING POLICE OFFICER FAMILIES FROM DOMESTIC VIOLENCE
}

\author{
Rafaqat Cheema
}

\begin{abstract}
Officer-involved domestic violence (OIDV) is a national problem, with police officer families having higher rates of domestic violence than non-police officer families. OIDV is also an underresearched problem with few studies or proposed solutions. Many victims of OIDV do not report their abuse precisely because their abuser is a police officer, whom they fear is in a unique position to protect him/herself from any legal consequences. Often, OIDV complaints are not investigated properly in a nonbiased manner. While a handful of police agencies around the country have developed specific policies and procedures to deal with OIDV, Washington State has enacted legislation that requires its police agencies to adopt OIDV-specific policies. The International Associations of Chiefs of Police (IACP), an organization that addresses various issues confronting law enforcement, has also developed a model policy on OIDV. This Note proposes that, in light of the Washington legislation and the model policy proposed by the IACP, each state should enact a statute that requires its police agencies to develop policies on OIDV. This Note also outlines a specific set of procedures that such statutes should, at a minimum, require its police agencies to adopt, ranging from educating police officers on domestic violence to developing guidelines on responding to and investigating OIDV complaints.
\end{abstract}

Keypoints for the Family Court Community:

- Officer-involved domestic violence (OIDV) is a serious problem within police officer families.

- Police officers face unique challenges that lead to a high rate of domestic violence.

- Police officer families need states' assistance in countering OIDV.

- OIDV can be countered by requiring police agencies to adopt guidelines for dealing with it.

Keywords: $\quad$ Domestic Violence; Officer Abuse; Officer-Involved Domestic Violence; OIDV; Police Officers; and State Regulation.

\section{INTRODUCTION}

Rosaura Torres, an author and partner at a publishing house, ${ }^{1}$ was involved in a physically abusive marriage. A native of Minnesota, Rosaura was married to her husband, a Philadelphia police officer who ascended to the top ranks of the police department, for sixteen years. ${ }^{2}$ During the nearly two decades of her marriage, Rosaura was beaten, kicked and choked by her husband. ${ }^{3}$ As a result, Rosaura has a detached retina, which has left her partially blind. ${ }^{4}$

Ignoring her repeated pleas to stop, Rosaura's husband continued his assault on her. ${ }^{5}$ Rosaura threatened to report him, but he told her that going to the police would amount to nothing. ${ }^{6}$ Unfortunately, he was right. ${ }^{7}$ Rosaura wrote to the police and city officials when her husband was up for promotion, detailing her husband's violent tendencies. ${ }^{8}$ Despite Rosaura's revelations, they ignored her letters and promoted her husband. ${ }^{9}$ Rosaura escaped the abuse in 2004 by ending her marriage. ${ }^{10}$ Her husband, who was never criminally charged for her injuries, has since retired from the police department and moved away from the city. ${ }^{11}$ Rosaura has been able to get back on her feet since then, recounting her experiences in a book and becoming an activist for abused spouses. ${ }^{12}$

Unfortunately, Rosaura's story is not an isolated incident. Reports show that at least forty percent of police officer families experience domestic violence as opposed to only ten percent of families generally. ${ }^{13}$ Another study of older and experienced police officers revealed a domestic violence rate

Corresponding: rcheema1@pride.hofstra.edu 
of twenty-four percent, nearly two and a half times higher than in non-police officer families. ${ }^{14}$ The causes of the high rate of domestic violence in police officer families can be attributed to the unique job related problems that police officers face. ${ }^{15}$ Reports show that police officers encounter a stressful work environment which leads to other problems like suicide, divorce, and alcoholism. ${ }^{16}$ Considering these factors, it should be no surprise that police officers also face high rates of domestic violence.

The problems confronted by police officers and their families are exacerbated when police departments do not respond effectively to them. ${ }^{17}$ Victims of OIDV are hesitant to report the crime because they fear retaliation in the form of further abuse from their spouse and worry that their complaints will not be taken seriously. ${ }^{18}$ Those that do report abuse find that departments often do not believe their claims or do not conduct investigations properly. ${ }^{19}$ Recognizing this problem, some police agencies have adopted OIDV specific policies, most notably the Chicago Police Department and the Nashville Police Department. ${ }^{20}$ States like Florida and New Jersey have also enacted model OIDV specific policies to encourage law enforcement agencies to utilize such guidelines. ${ }^{21}$ Legislation enacted in Washington State requires its law enforcement agencies to devise policies and procedures for OIDV. ${ }^{22}$ Congress has also addressed OIDV by passing the Crystal Judson Domestic Violence Protocol Program, part of the reauthorization of the Violence against Women Act. $^{23}$ The Crystal Judson Domestic Violence Protocol Program provides law enforcement agencies with federal funding for implementing OIDV protocols. ${ }^{24}$ This program was passed in light of an OIDV case in Washington State, which resulted in the murder of a woman by her police officer husband. ${ }^{25}$

This Note proposes that states should utilize the Washington legislation, as well as the model policy devised by the International Associations of Chief of Police to counter OIDV. ${ }^{26}$ Specifically, states should enact legislation similar to that of Washington State, which requires law enforcement agencies operating in that state to develop and implement OIDV specific policies. ${ }^{27}$ Furthermore, like the Washington solution, the legislation enacted by each state should devise a set of policies, which at a minimum, each police agency is required to follow, with discretion to enact and mandate other policies. ${ }^{28}$ This Note examines those policies and guidelines which each state should statutorily require its law enforcement agencies to follow.

The policies that this Note suggests will address different aspects of the problem of OIDV. The suggested policies include provisions for educating and training officers about the dimensions of OIDV. ${ }^{29}$ This requirement is inspired by Florida State University's program of partnering with the Florida Department of Law Enforcement to, among other things, develop a model policy on OIDV and educate officers on OIDV. ${ }^{30}$ Each state should also require police agencies to have procedures in place for dealing with those claiming to be victims of OIDV. Under this system, complainants will be informed of the status of the investigation and will be given contact information for domestic violence victim advocates and any other pertinent information. ${ }^{31}$ Drawing on the experience of programs like the one created by the New York Police Department (NYPD), this Note also proposes that police agencies develop counseling programs for the benefit of any officer who is facing problems such as job related stress. ${ }^{32}$

In order to ensure that police officers are not classified as guilty as soon as an accusation is levied against them, each state should require its police agencies to conduct thorough and impartial investigations. ${ }^{33}$ Furthermore, while the investigation is ongoing, administrative entitlements and legal rights of the accused officer should be preserved. ${ }^{34}$ As in the Washington solution, these policies and procedures set out by each statute should be mandatory, with discretion for police agencies to enact other procedures as they see fit. ${ }^{35}$

Part II of this Note provides an overview of OIDV and its causes. Part III analyzes the current state of legislation on officer-involved domestic violence as well as why it falls short in addressing OIDV. Part IV discusses in detail the legislation proposed by this Note as well as guidelines for implementing it. Part V addresses the arguments critics might pose in opposition to the proposed legislation. Part VI concludes with a summary of the problem and the proposed solution. 


\section{OFFICER-INVOLVED DOMESTIC VIOLENCE IN THE UNITED STATES}

\section{A. GENERAL OVERVIEW OF THE PROBLEM}

Domestic violence is a problem which seems to know no gender, racial, economic, or occupational boundaries. ${ }^{36}$ It should be no surprise that domestic violence affects police officers too. ${ }^{37}$ After all, police officers are a microcosm of the society and therefore are bound to be affected by the problems plaguing it. Police officers, however, face distinct challenges that contribute to high rates of domestic violence within their families. ${ }^{38}$

Research on OIDV has been so inadequate that the problem cannot be measured in exact terms. ${ }^{39}$ Therefore, it has been difficult to obtain information concerning the frequency with which OIDV occurs and is reported. ${ }^{40}$ The fact that there is no central reporting system does not help. ${ }^{41}$ Some analysts have even resorted to directly asking officers to confess how often they commit abuse. ${ }^{42}$ Some studies show that in at least forty percent of police officer families women face domestic violence. ${ }^{43}$ This is in contrast to the twenty five percent figure for American women overall. $^{44}$

The problem of OIDV in turn creates more problems, notably, improper investigations of OIDV by police agencies. ${ }^{45}$ Officers who commit domestic violence sometimes utilize their police power and status to prevent the victim from seeking recourse. ${ }^{46}$ While there are no solid statistics on the issue, it has been reported that, when it comes to officer-involved domestic violence investigations are not done properly. ${ }^{47}$ OIDV complaints are essentially minimized by police agencies and not taken as seriously as they should be. ${ }^{48}$ An OIDV investigation in Florida is representation of this problem and paints a bleak picture. ${ }^{49}$ In that particular investigation, a police officer was vindicated of the murder of his wife in less than twenty-four hours, with relevant evidence ignored and no interviews conducted of relevant parties, raising questions on the adequacy of the investigation. $^{50}$

At times, the accusations are even turned against the victim by the officers to whom the victim is reporting the crime. ${ }^{51}$ In addition, victims are haunted by fear of retaliation from the abusive partner. ${ }^{52}$ Many of these women will, unfortunately, end up not even reporting their abuse. ${ }^{53}$ Improper investigations of OIDV complaints have been attributed to the code of silence among police officers, where police officers will refrain from reporting or properly investigating fellow officers. $^{54}$

However, the code of silence for victims of OIDV is unique. ${ }^{55}$ It is a code of silence where not only police officers, but prosecutors and domestic violence victim advocates also sometimes refrain from coming to the aid of the victims. ${ }^{56}$ It has even been reported that domestic violence victim advocates sometimes choose to ignore OIDV complaints so as not to alienate the police agencies they rely upon for assistance in other domestic abuse cases. ${ }^{57}$ Prosecutors can also become less diligent in pursuing OIDV complaints because they too need these same police officers for help in other cases. $^{58}$

Studies have shown that domestic violence complaints which do end up reaching the investigation phase typically are investigated informally without official analyses or reports. ${ }^{59}$ Furthermore, studies also show that officers who are found guilty of having engaged in domestic violence are unlikely to be relieved of their duties, arrested or prosecuted. ${ }^{60}$ As can be inferred, such biases and inadequacies make the life of the victim extremely problematic and difficult. ${ }^{61}$ Unfortunately this is only one of the problems victims of OIDV are facing.

\section{B. WHY DO POLICE OFFICER FAMILIES EXPERIENCE DOMESTIC VIOLENCE?}

High rates of OIDV in police officer families may originate in the nature of a career in law enforcement. ${ }^{62}$ Policing is a rather stressful job. ${ }^{63}$ Police officers report high rates of divorce, alcoholism, and suicide. ${ }^{64} \mathrm{~A}$ career in law enforcement brings challenges not faced by those in other 
careers. ${ }^{65}$ Unlike those in many other workplaces, police officers are exposed to violence and suffering routinely. ${ }^{66}$ Police officers also tend to work erratic schedules which prevent them from spending sufficient time with families. ${ }^{67}$ Furthermore, even the way in which police officers are supervised has also been said to be a cause of job stress: the rigid, militaristic management style and the extremely bureaucratic organization of police agencies make it difficult for police officers to cope on an everyday basis. ${ }^{68}$

Such job related stresses have been noted to contribute to, among other problems, domestic violence in police officer families. ${ }^{69}$ Aside from domestic violence, the work environment faced by police officers is said to be in and of itself a cause of stress among the officer's family members. ${ }^{70}$ Various aspects of the officer's job can cause stress in the family ranging from an erratic work schedule, to not enough discussion on the part of the officer to discuss his or her job as well as the perception on the part of family members that the officer prefers to spend time with coworkers rather than with family. ${ }^{71}$ Although it goes without saying, it must be said that this kind of family environment is most likely an incubator for violence in the home.

Police officers thus face a challenging work environment, which contributes to a high rate of domestic violence and a tough living environment for their families. ${ }^{72}$ These factors may lead to other problems as well. ${ }^{73}$ According to one report, forty percent of police officers suffer from a sleep disorder, at least double the estimated rate of the general population. ${ }^{74}$ Estimates show that possibly twenty percent of police officers are "problem drinkers." ${ }^{, 75}$ Although this rate might be less than that of Americans overall, it demonstrates that many officers drink to escape the stresses of their job. ${ }^{76}$ Suicide has also been noted to be a problem amongst law enforcement professionals, occurring 1.5 times more frequently than in the general population. ${ }^{77}$ Furthermore, it has also been reported that police officers face higher divorce rates. ${ }^{78}$ All of these various issues show that domestic violence is just one of the many serious potential consequences faced by police officers in a stressful career.

Apart from the stressful work environment there is another notable cause of domestic violence in police officer families - alcohol. The consumption of alcohol is considered to be a part of the police culture and is also a way for police officers to cope with their stressful work environment. ${ }^{79}$ As has been hinted to earlier, as well there is a correlation between the stressful work environment of police officers and alcohol use, however there is also a correlation between alcohol consumption and domestic violence itself. ${ }^{80}$ Simply put, consumption of alcohol by police officers is said to be a cause of domestic violence. ${ }^{81}$ One source has even noted that the majority of OIDV cases nationwide are related to alcohol use. ${ }^{82}$ This issue prompted the chief of police of Tucson, Arizona, for example, to acknowledge the relationship between alcohol and OIDV. ${ }^{83}$

\section{CURRENT STATE OF LAW CONCERNING OFFICER-INVOLVED DOMESTIC VIOLENCE}

On the federal level, Congress has enacted the Crystal Judson Domestic Violence Protocol Program as part of the reauthorization of the Violence Against Women Act. ${ }^{84}$ This program provides funding to law enforcement agencies to implement protocols to counter OIDV. ${ }^{85}$ Therefore, any police agency seeking to develop a procedure or set of policies on OIDV has the option to finance its program through federal funding. ${ }^{86}$ States like Florida and New Jersey have also adopted model policies on OIDV. ${ }^{87}$ Washington State's statute requires its police agencies to have policies and procedures in place specifically for OIDV. ${ }^{88}$

The Washington State legislation was signed into law in 2004 by then Governor Gary Locke. ${ }^{89}$ This bill was enacted in light of Crystal Brame's death, who was murdered by her husband, the local police chief in Tacoma, Washington. ${ }^{90}$ Her death brought the issue of OIDV, the unique problems surrounding it, and the response of law enforcement agencies, into the limelight in the state of Washington. ${ }^{91}$ The bill requires Washington law enforcement agencies to develop policies for OIDV. ${ }^{92}$ Requirements of the law include, among other things, screening applicants for any domestic violence 
history, sharing information on OIDV training with other agencies, offering information on counseling options to officers, informing the individual making a domestic violence complaint about the investigation's status, and requiring officers to report a fellow officer's involvement in domestic violence. ${ }^{93}$ These requirements are only meant to set a minimum standard while allowing agencies further discretion in developing their own policies for OIDV. ${ }^{94}$

At the local level, some police agencies have a distinct policy on OIDV. ${ }^{95}$ A survey by the New York Times in conjunction with PBS, discovered that a quarter of the fifty-six largest police departments that responded to the survey have adopted the specific OIDV model policies drafted by the International Associations of Chiefs of Police (IACP). ${ }^{96}$ The IACP, an organization whose goal is the advancement of the law enforcement profession, has also recognized the seriousness of the problem of OIDV. ${ }^{97}$ As mentioned earlier, Florida State University (FSU) has also recognized the urgency of the OIDV problem and has proposed innovative solutions for its home state. ${ }^{98}$ FSU's Institute for Family Violence Studies has developed a program specifically tailored towards OIDV. ${ }^{99}$ Among other things, the program provides a prevention-based course to educate police officers on OIDV ${ }^{100}$ In addition, the program seeks to foster a police culture in which OIDV is considered to be contrary to police ethics. ${ }^{101}$ As mentioned earlier, the IACP has also developed a model policy on OIDV and urged law enforcement agencies to voluntarily adopt it. ${ }^{102}$ Only Nashville, the aforementioned NY Times survey found, has adopted the policy in its entirety, with Charlotte, Chicago, and Columbus following most of the provisions of the model policy proposed by the IACP. ${ }^{103}$

There are multiple problems with the current state of legislation, and indications are that only a minority of police agencies around the country has adopted a policy on OIDV ${ }^{104}$ In effect, police agencies are free to decide whether to address the problem of OIDV or not. This self-regulation has resulted in discrepancies in how different police departments treat OIDV: some police departments have distinct policies for OIDV, but others do not; some may relieve the assailant of his or her job while others may not. ${ }^{105}$

It has also been reported that police officers that perpetrate domestic violence can get away with it without facing consequences. ${ }^{106}$ One victim of domestic violence stated that, when she would reach out to law enforcement after being assaulted by her police officer husband, the responding officers

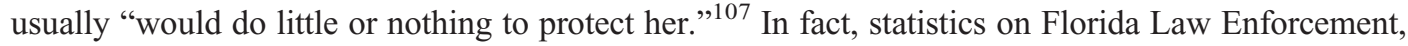
for instance, show that between 2008 and 2012, twenty-eight percent of police officers were still working at their respective department a year after domestic violence complaints had been lodged against them. ${ }^{108}$ Some departments have systematically addressed the problem, while others have not. ${ }^{109}$ All departments should address OIDV systematically. This goal can only be achieved by enacting legislation mandating they do so.

\section{ADOPTION OF A STATE STATUTE}

Subsequent to the passage of Washington's legislation requiring law enforcement agencies to develop OIDV policies, a few members of Congress sent a letter to all the states urging them to adopt the Washington legislation. ${ }^{110}$ This Note proposes that states should heed the advice of Congress. Specifically, this Note proposes that states adopt legislation modeled on the Washington State statute and also utilize the IACP model policy. The proposed state legislation would make it mandatory for law enforcement agencies to adopt and develop OIDV policies. ${ }^{111}$ The legislation would also set out minimum guidelines which police agencies would be required to adopt, similar to the Washington statute. ${ }^{12}$ Police agencies would also have discretion to adopt any further guidelines they see fit. It is also important to state here that this Note is not meant to be an exhaustive overview of the solutions proposed by the Washington legislation and the IACP. Rather, this Note aims to familiarize readers with the spirit of these solutions in the hope that it will inspire others to recognize and address this problem.

Furthermore, mandatory measures are important because a notable problem in OIDV has been the improper investigation of complaints. It has been reported that OIDV investigations have been 
conducted improperly with the officer under investigation essentially being given special treatment. ${ }^{113}$ The solution proposed here will help to ameliorate one of the biggest problems with OIDV, namely, the sometimes unhealthy relationship between complainants and police agencies. ${ }^{114}$

\section{A. STATE REGULATION EXPLORED FURTHER}

Mandatory minimum guidelines, which each state should require its law enforcement agencies to adopt, should include the following:

\section{Educational Programs for Police Officers}

Although the Washington statute does not explicitly require police agencies to formally educate their officers on OIDV, ${ }^{115}$ such a measure would probably strengthen the anti-domestic violence stance of that state. Every agency should be required to educate its police officers on OIDV issues. ${ }^{116}$ This comports with FSU's efforts to partner with law enforcement to educate officers on OIDV. ${ }^{117}$ Although education programs will focus on acquainting officers with the problems and causes of OIDV, individual agencies will have discretion regarding the nature and extent of their educational efforts. This is important because, given the diversity of police forces around the country, ${ }^{118}$ it is the individual agencies who know their officers best. Furthermore, each state should require its law enforcement agencies to train their officers on the OIDV policies that that are being adopted. ${ }^{119}$ It is essential that officers know what is expected of them.

\section{Screening of Candidates}

The Washington legislation requires that police agencies thoroughly screen job applicants for any current or past domestic violence incidents. ${ }^{120}$ Police agencies should adopt screening procedures designed to disclose such information. ${ }^{121}$ Police agencies should also develop standards on dealing with the employment status of those being investigated for domestic violence and those who are found to have perpetrated it. ${ }^{122}$ Furthermore, as required by the Washington statute, police agencies should develop policies on self-reporting for employees who have been accused of, or are being investigated for, domestic violence complaints by any other agency. ${ }^{123}$

\section{Counseling of Officers}

States should require their local police agencies to provide counseling services to their officers implicated in OIDV. This approach is inspired by agencies like the NYPD and Los Angeles Police Department who have counseling programs in place for their officers. ${ }^{124}$ Once police officers have been hired, it is both in the interests of the employee and the employer to foster a healthy work environment. For this reason, counseling should be available to those officers who are facing stress, family problems, or any other problem which, if unchecked, could lead to domestic violence within the household. Ultimately, it would be left to the police agencies themselves to develop the specifics of their counseling program, but forming a partnership with a nearby hospital or university which has access to such counseling services might help in the task.

Although the Washington solution does not explicitly require police agencies to offer counseling services to their employees, it does require agencies to offer information about treatment programs upon request or to officers who have been alleged to have committed domestic violence. ${ }^{125}$ The NYPD, however, provides counseling in order to assist its officers with job related stress issues that might arise. ${ }^{126}$

Like the NYPD counseling initiative, the services proposed here seek to assist police officers with diverse issues and problems. ${ }^{127}$ Such a program will likely not only help officers in their domestic life but will also help them become better employees in the workplace. ${ }^{128}$ It has been reported that 
when employers utilize such measures, the employees benefit through higher job productivity, increased job satisfaction, improved work relationships, and less absenteeism. ${ }^{129}$ Therefore, providing counseling services will benefit both the agency and the officer.

\section{Responding to OIDV Complaints}

The legislation proposed here requires that each complaint of OIDV be promptly investigated and that the complainant be informed of the status of the investigation. This requirement is comparable to the approach taken by Washington. ${ }^{130}$ While each police agency should be free to devise its own variations on this requirement, there are some recommended guidelines that should be followed. ${ }^{131}$ As in the model policy proposed by the IACP, the officials responding to the complaint should ensure that the scene of the alleged crime is protected, and any relevant evidence or accounts are preserved. ${ }^{132}$ The victim should also be made aware of the department's policy on OIDV, the standard for an arrest, and the procedures for obtaining a protective order pursuant to the IACP model policy outlines. $^{133}$

Under these suggested guidelines, departments would also be free to follow their standard procedures in investigating OIDV. ${ }^{134}$ Follow-up investigations should be conducted thoroughly to ensure the acquisition and preservation of relevant information and evidence. ${ }^{135}$ Upon a showing of probable cause, an arrest should be made. In the event that an arrest is not made, a written report of the incident should be drafted and filed in accordance with the IACP model policy outlines. ${ }^{136}$

\section{Investigation of the Accused Police Officer}

The legislation proposed here requires that the department conduct separate administrative and criminal investigations of an OIDV complaint as recommended by the IACP Model policy. ${ }^{137}$ The IACP policy requires that the administrative investigation be conducted by the Internal Affairs Division of the police agency or an investigator appointed by the chief of police. ${ }^{138}$ The goal of the administrative investigation would be to determine whether the accused has violated any administrative or departmental policies. ${ }^{139}$

Additionally, as suggested by the IACP, a criminal investigation should be conducted by the department, just as it would conduct any other criminal investigation. ${ }^{140}$ While the investigation is ongoing, the department should take all necessary steps to ensure that the rights of the accused are protected. ${ }^{141}$ Such measures can help ensure that the accused is treated fairly while the investigation is being conducted. Finally, the agency should take appropriate action against the officer if the investigation concludes that the accused did, in fact, perpetrate violence on his/her partner. ${ }^{142}$ Such action, if the agency deems appropriate, may include termination from the job. ${ }^{143}$

\section{Additional Measures}

The Washington legislation encourages police agencies to work with fellow law enforcement agencies in addressing the problems of OIDV. ${ }^{144}$ Police agencies should be mandated to develop procedures to notify fellow agencies upon becoming aware that a fellow agency's officer has been accused of domestic violence. ${ }^{145}$ Furthermore, agencies should be mandated to share and provide access to other agencies on relevant OIDV training that they have developed. ${ }^{146}$ It is also important that procedures be developed by police agencies to update complainants about the status of the investigation and giving them contact information for domestic violence victim advocates, or any other pertinent information. ${ }^{147}$

In order to ensure that police agencies are complying with all recommended OIDV statutory requirements, it is necessary to establish a mechanism for oversight. ${ }^{148}$ This Note proposes that a committee, or an association consisting of representatives from statewide organizations representing state and local enforcement officers, and a statewide organization which provides education and 
training for agencies which serve domestic violence victims, be formed to oversee police agency compliance. ${ }^{149}$ Police agencies should advise the association of all relevant policies and procedures they have developed in regards to OIDV. ${ }^{150}$ The association, in turn, should provide a list to the state governor and state legislature of those agencies who have not complied with the requirements of adopting OIDV specific policies and procedures. ${ }^{151}$

\section{B. TURNING AWAY FROM THE WASHINGTON SOLUTION}

It has been reported that police officers who act as whistleblowers regarding misconduct by their fellow officers, and who break the "code of silence," end up making the work environment very difficult for themselves. ${ }^{152}$ Those who break the code can be ostracized by their peers or face threats. ${ }^{153}$ This problem has been referred to as the "Blue Code of Silence." 154 The problem is so pervasive that it would be safe to assume that the fight against corruption in some police departments is hampered by the code of silence. ${ }^{155}$ Efforts have been underway to study, address, and counter this problem. ${ }^{156}$ One particular suggestion essentially calls for changing the culture of the police department in which officers have positive role models in the form of leaders who are ethical. ${ }^{157}$ Having such leadership in the police department can aid in improving communication with lower-level officers thereby making it easier for them to report misconduct. ${ }^{158}$ Notably, the collaboration in Florida between FSU and law enforcement agencies represents a step toward changing this aspect of police culture through an educational curriculum. ${ }^{159}$

Jurisdictions around the country seem to have their own individual ways of regulating reporting of a fellow officer's misconduct. ${ }^{160}$ The NYPD, for example, requires officers to report any "corruption or serious misconduct." 161 The Washington legislation has also attempted to address this issue by requiring officers to report on their colleagues when they have allegedly committed domestic violence. ${ }^{162}$ Nevertheless, the code of silence continues to be a serious obstacle. ${ }^{163}$

The solution proposed here, however, does not advocate any of the aforementioned measures. Particularly, this solution does not advocate for or against the aforementioned approach taken by the Washington legislation. ${ }^{164}$ This is so because, as the preceding has made clear, this is a controversial and complicated issue that should not be conjoined with the problem of OIDV but should be analyzed and dealt with separately. By dealing with this issue separately and not conjoining it with the problem of OIDV, law enforcement agencies will be better able to deal with both problems. Therefore, the legislation proposed here leaves it up to the individual police agencies to decide on the issue of whether a police officer should be required to report a fellow officer's perpetration of domestic violence.

\section{COUNTERARGUMENTS AGAINST STATES REQUIRING POLICE AGENCIES TO ADOPT POLICIES ON OIDV}

\section{A. THE COST AND COMPLICATIONS OF IMPLEMENTING THIS PROGRAM}

Critics of the proposed OIDV measures may cite the financial burden police agencies will face in implementing the program required by the proposed statute. ${ }^{165}$ As discussed earlier, Congress has passed a bill, which invites law enforcement agencies to apply for federal funding to develop OIDV protocols. ${ }^{166}$ This financial backing will greatly facilitate the establishment and implementation of OIDV programs. Even if the federal government is not able to provide funding, the situation is serious enough to warrant financial support from state governments as the solutions proposed here address serious family problems and aim to protect the integrity of our police departments. Therefore, it would be reasonable to expect the states to participate in efforts to ensure that their officers remain free from the taint of domestic violence. 


\section{B. MANY CONCERNS OF DOMESTIC VIOLENCE VICTIMS HAVE BEEN LEFT UNADDRESSED}

Critics of this proposal might also argue that it fails to allay some of the concerns that victims of OIDV might have. It has been reported that one of the reasons victims of domestic violence choose not to report their abuse is because of fear of retaliation from their partner. ${ }^{167}$ It is possible that the fear of retaliation is common to domestic violence victims in general and therefore not limited to situations where the perpetrator might be a police officer. ${ }^{168}$ In any event, fear of retaliation should not prevent adoption of the proposed statute and should be looked as characteristic to the problem of domestic violence in general and addressed accordingly.

Furthermore, OIDV victims may also be deterred from reporting abuse because of the possibility that the assailant may lose his/her job. ${ }^{169}$ While this is indeed a problem, the solution proposed here says nothing about the job status of those who are found to have committed domestic violence. Rather, the legislation proposed here recommends that the states defer to the individual police agencies to resolve the employment status of those who have perpetrated domestic violence. This is so, as will be further explained, because of the negative economic effect on the victim if the batterer was to lose his/her job.

Conversely, those who advocate a tougher approach to OIDV will likely criticize the fact that the proposed solution does not require automatic job loss of the perpetrators. If termination of employment were to be imposed, victims would suffer doubly; first by being subjected to abuse by their partner and second by being put in a financially precarious situation. ${ }^{170}$ An officer who loses his/her job will not be able to contribute to household and childcare expenses. Such a situation might inhibit, instead of encourage, the reporting of domestic violence. The phrase "anticooperative effect of law" has been used to describe such an effect, which promotes noncooperation with law enforcement agencies instead of helping the victim. ${ }^{171}$ The Chicago police department has taken notice of this problem and rejected a zero tolerance approach toward officers who commit domestic violence, believing that if abusers are punished too harshly victims might not report the crime. ${ }^{172}$

On the other hand, for both police officers and ordinary citizens, it is possible that a zero tolerance policy might provide a strong deterrent to domestic violence. ${ }^{173}$ Proponents argue that such a policy will send a strong message for the nontoleration of domestic violence. ${ }^{174}$ However, given the unclear effect that a zero tolerance policy might have on the lives of the victims, it should be left to the discretion of the individual police agencies to decide whether to enforce such a measure.

\section{THIS SOLUTION VILIFIES THE POLICE}

Critics of the proposed legislation might also argue that the problem and solutions proposed here are vilifying the police by specifically pointing out domestic violence within their ranks. After all, research shows that domestic violence is not just a police officer problem but affects other segments of society like "college students or military families." 175 Describing the problem of OIDV and proposing solutions does not vilify the police. Rather, it encourages help for police officers and their families. Addressing OIDV will help many police officer families caught in this cycle of violence. It should not be simply dismissed as another tactic being used to malign our police officers.

Traditional views on domestic violence tend to deal with perpetrators only after they have acquired the label of domestic violence perpetrators, usually by offering treatment services to them. ${ }^{176}$ Many courts have mandated counseling programs for domestic violence perpetrators from which the vast majority end up dropping out. ${ }^{177}$ The solution proposed here, however, tries to intervene before officers have acquired the label of a perpetrator. Counseling services and other carefully balanced protocols, which are proposed here, seek to foster a healthy relationship between officers and police agencies. In addition, this solution also ensures that accused officers receive due process in the administrative and criminal investigations of OIDV complaints thereby preventing them from being unfairly labeled as perpetrators. All this shows that the goal is to assist officers rather than vilify them. 


\section{CONCLUSION}

OIDV is a problem that exists beneath the surface. Until recently, not many individuals have studied, documented, or even acknowledged its severity. This leaves victims in a helpless place, often in fear that they cannot turn to the law, the police, or anyone else for help. Thus, many victims find themselves in an endless cycle of violence and lose confidence in the policing system. Such a problem also taints the performance and reputation of our police officers. In order to foster both the integrity of law enforcement and the welfare of our police officers as well as their families, states must ensure that OIDV is seriously addressed.

\section{NOTES}

1. LinkedIn Profile of Rosaura Torres, LinKEDIN, https://www.linkedin.com/pub/rosaura-torres/17/799/188 (last visited Dec. 17, 2014).

2. David Gambacorta \& Dana DiFilippo, Domestic Terrors, Philly (Sept. 11, 2014), http://articles.philly.com/2014-09-11/ news/53775430_1_police-officer-police-families-philadelphia-police-department.

3. Id.

4. Id.

5. Id.

6. Id.

7. Id.

8. Id.

9. Id.

10. Id.

11. Id.

12. Id.

13. Conor Friedersdorf, Police Have a Much Bigger Domestic Abuse Problem than the NFL Does, The AtLantic (Sep. 19, 2014), http://www.theatlantic.com/national/archive/2014/09/police-officers-who-hit-their-wives-or-girlfriends/380329/; National Center for Women and Policing, Police Family Violence Fact Sheet, http://womenandpolicing.com/violenceFS.asp\#notes (last visited Oct. 24, 2014).

14. Friedersdorf, supra note 13; National Center for Women and Policing, supra note 13.

15. Nat'l Crim. Just. Reference Serv., On The Job Stress In Policing- Reducing it, preventing it, NAT'L InST. Just. J. 19-21 (Jan. 2000), available at https://www.ncjrs.gov/pdffiles1/jr000242d.pdf.

16. Id.; Ralph Heibutzki, The Effects of Being a Police Officer, Hous. CHron., http://work.chron.com/effects-being-policeofficer-8866.html (last visited Feb. 7, 2015).

17. Sarah Cohen et al., Departments Are Slow to Police Their Own Abusers, N.Y. Times (Nov. 23, 2013), http://www. nytimes.com/projects/2013/police-domestic-abuse/.

18. Id.

19. Kevin Fagan, Police Domestic Violence Nearly Twice Average Rate, S.F. Gate (Jan. 15, 2012), http://www.sfgate. $\mathrm{com} /$ bayarea/article/Police-domestic-violence-nearly-twice-average-rate-2536928.php.

20. Cohen et al., supra note 17.

21. State of New Jersey, Departmental Policy for Handling of Domestic Violence Incidents Involving Law Officers (Dec. 11, 2009), http://www.nj.gov/oag/dcj/agguide/DV-Model-Policy-Final-12-11-09.pdf;

Florida State University, Florida's Model Policy on Officer Involved Domestic Violence (2010), https://www.dcf.state.fl.us/programs/domesticviolence/publications/docs/FloridaModelPolicyonOfficerDV2010.pdf.

22. Gina Barton, Murder by Law Officers, Met with Action, Inertia, Journal Sentinel (Dec. 22, 2011), http://www.jsonline. com/watchdog/watchdogreports/murder-by-law-officers-met-with-action-in-washington-inertia-in-wisconsin-sj3dojl-136124378. html; Press Conference Speakers, Men's Domestic Abuse Checkup, http://depts.washington.edu/mcheckup/MDACU\%20Press\%20Conference\%20Biographies.pdf (last visited May.12, 2016) (Hereinafter Press Conference); WaSH. Rev. Code AnN. § 10.99.090 (2006).

23. Stacey Mulick, Promises Made, Some Promises Kept, Tacoma News Trib. (Apr. 21, 2013), http://www.courts.wa.gov/ content/PublicUpload/eclips/4.22.13\%20TNT2.pdf; Press Conference, supra note 22. 42 U.S.C.A. § 3796gg (2013).

24. Id.

25. Id; Ann Carline Drake, Honoring Crystal Judson Brame: 10 Years of Triumphs and Tears (Apr. 26, 2013), http:// annecarolinedrake.com/2013/04/26/honoring-crystal-judson-brame-10-years-of-triumphs-and-tears/.

26. Wash. Rev. Code Ann. § 10.99.090 (2006); Int'l Ass'n of Chiefs of Police, Policy on Domestic Violence by Police Officers, http://www.iacp.org/Portals/0/documents/pdfs/MembersOnly/DomesticViolencebyPolicePolicy.pdf (last visited Sept. $13,2015)$. 
27. Barton, supra note 22; WASH. Rev. Code AnN. § 10.99.090 (2006).

28. Id.

29. Karen Oehme et al., Protecting Lives, Careers, and Public Confidence: Florida's Efforts to Prevent Officer-Involved Domestic Violence, 49 Fам. Cт. Rev. 84, 87 (2011).

30. Id. at 86,87 .

31. Wash. Rev. Code Ann. $§ 10.99 .090$ (2006).

32. Michael Wilson \& Cara Buckley, Worried about Stigma, Officers Often Opt out Of Police Counseling, N.Y. TIMES (Oct. 2, 2008), http://www.nytimes.com/2008/10/03/nyregion/03cops.html?_r=2\&.

33. Wash. Rev. Code Ann. § 10.99.090 (2006).

34. Int'l Ass'n of Chiefs of Police, supra note 26.

35. Wash. Rev. Code Ann. § 10.99.090 (2006).

36. Alanna Vagianos, 30 Shocking Domestic Violence Statistics That Remind Us It's An Epidemic, Huffington Post (Oct. 23, 2014), http://www.huffingtonpost.com/2014/10/23/domestic-violence-statistics_n_5959776.html; Eliza Shapiro, Domestic Violence Among the Wealthy Hides Behind "Veil of Silence," DaILy BeAst (Feb. 28, 2013), http://www.thedailybeast.com/ articles/2013/02/28/domestic-violence-among-the-wealthy-hides-behind-veil-of-silence.html.

37. Laura Beck, Forty Percent of Police Families Experience Domestic Violence, Jezebel (Mar. 17, 2013), http://jezebel. com/5991019/forty-percent-of-police-officer-families-experience-domestic-violence.

38. Nat'1 Crim. Just. Reference Serv., supra note 15, at 19-21.

39. Friedersdorf, supra note 13; Cohen et al., supra note 17.

40. Cohen et al., supra note 17.

41. Id.

42. Id.

43. Fagan, supra note 19.

44. Id.

45. Id.

46. Id.; Cohen et al., supra note 17.

47. Cohen et al., supra note 17; Sarah Childress, A Systemwide Failure, PBS (Nov. 26, 2013), http://www.pbs.org/wgbh/ pages/frontline/criminal-justice/death-in-st-augustine/a-systemwide-failure/.

48. Id.

49. Walt Bogdanich \& Glen Silber, Two Gunshots On a Summer Night, N.Y. Times (Nov. 23, 2013), http://www.nytimes. com/projects/2013/two-gunshots/.

50. Id.

51. Fagan, supra note 19.

52. Id.

53. Id.

54. Id.

55. Id.

56. Id.

57. Id.

58. Id; Childress, supra note 47.

59. Friedersdorf, supra note 13.

60. Id.

61. Gambacorta \& DeFilipo, supra note 2.

62. Nat'1 Crim. Just. Reference Serv., supra note 15, at 20-21.

63. Id. at 19 .

64. Id.

65. Id.

66. Id.

67. Id.

68. Id.

69. Id. at 20-21.

70. Id. at 20 .

71. Id. at 20 .

72. Id. at 19-21.

73. Mark Bond, The Impact of Stress and Fatigue on Law Enforcement Officers and Steps to Control It, In PUBLIC SAFETY (Feb. 24, 2014), http://inpublicsafety.com/2014/02/the-impact-of-stress-and-fatigue-on-law-enforcement-officers-and-steps-to-control-it/.

74. Anahad O'Connor, Sleep Problems in Police Officers Take Heavy Toll, N.Y. Times (Dec, 20, 2011), http://well.blogs. nytimes.com/2011/12/20/sleep-problems-common-in-police-officers/; Sleep Disorders, ANXIETy \& Depression Ass'N OF AMERICA, http://www.adaa.org/understanding-anxiety/related-illnesses/sleep-disorders (last visited Sept. 13, 2015).

75. Tanya Eiserer, They Drink When They're Blue: Stress, Peer Pressure Contribute to Police's Alcohol Culture, DaLlas Morning News (Jan. 15, 2012), http://www.dallasnews.com/investigations/headlines/20120115-they-drink-when-theyre-bluestress-peer-pressure-contribute-to-polices-alcohol-culture.ece. 
76. Id; Carl Nierenberg, Alcohol Disorders: Nearly 1 in 3 Adults Are Problem Drinkers, Live ScIEnCE (June 3, 2015), http://www.livescience.com/51066-alcohol-use-disorders-prevalence-us.html.

77. Pamela Kulbarsh, Police Suicides Drop in 2012, Officer (Jan. 9, 2013), http://www.officer.com/article/10850327/ police-suicides-drop-in-2012.

78. Ashley Kewish \& Alex Cabrero, Statistics of Domestic Violence, Divorce Higher for Families, KSL (Jan. 17, 2014), http://www.ksl.com/?sid=28395356.

79. Elizabeth A. Willman, Alcohol Use Among Law Enforcement, 2 J.L. ENFORCEMENT 1-2 (2012).

80. James Genovese, Alcoholism among Law Enforcement Personnel: It's Unique Challenges, MiLEstone Group LLC, http://www.milestonegroupnj.com/?page_id=348 (last visited Jan. 6, 2016).

81. Id.

82. Id.

83. Police Chiefs Discuss a Tough Issue: Alcohol and Drug Abuse by Officers, Subject to Debate (Police Executive Research Forum, Washington, D.C.), Sept./Oct. 2012, at 2, available at http://www.policeforum.org/assets/docs/Subject_to_ Debate/Debate2012/debate_2012_sepoct.pdf.

84. Mulick, supra note 23; Ann Carline Drake, Honoring Crystal Judson Brame: 10 Years of Triumphs and Tears (Apr. 26, 2013), http://annecarolinedrake.com/2013/04/26/honoring-crystal-judson-brame-10-years-of-triumphs-and-tears/; Press Conference, supra note 22; 42 U.S.C.A. § 3796gg (2013).

85. Id.

86. Id.

87. State of New Jersey, supra note 21; Fla. St. Univ., Florida's Model Policy on Officer Involved Domestic Violence (2010), https://www.dcf.state.fl.us/programs/domesticviolence/publications/docs/FloridaModelPolicyonOfficerDV2010.pdf.

88. Barton, supra note 22; Wash. Rev. Code Ann. § 10.99.090 (2006).

89. Press Conference, supra note 22.

90. Barton, supra note 22 .

91. Id.

92. Id; Wash. Rev. Code Ann. 10.99 .090 (2006).

93. Id.

94. Id.

95. Cohen et al., supra note 17.

96. Id.

97. Mission, Int'L Ass'N of Chiefs of Police, http://www.theiacp.org/Mission (last visited Sept. 13, 2015); Int'1 Ass'n of Chiefs of Police, supra note 25.

98. Oehme et al., supra note 29 , at 87.

99. Id. at 86 .

100. Id. at 87; Stephanie Salvatore, Program Hopes to Reduce, Prevent Officer Involved Domestic Violence, WCTV (Nov. 29, 2010), http://www.wctv.tv/home/headlines/Program_Hopes_to_Reduce_Prevent_Officer_Involved_Domestic_Violence_ 111000774.html.

101. Oehme et al., supra note 29 , at 87.

102. Cohen et al., supra note 17.

103. Id.

104. Id.

105. Id.

106. Id.

107. Id.

108. Id.

109. Id.

110. Letter by Congress of the United States, Police Domestic Violence, http://policedomesticviolence.com/lettertoallstates.htm, (last visited Feb. 4, 2015).

111. Wash. Rev. Code AnN. § 10.99.090 (2006); Barton, supra note 22.

112. Wash. Rev. Code AnN. § 10.99.090 (2006); Barton, supra note 22.

113. Bogdanich \& Silber, supra note 49.

114. Fagan, supra note 19.

115. Wash. Rev. Code AnN. § 10.99 .090 (2006).

116. Oehme et al., supra note 29, at 87 ; Salvatore, supra note 100.

117. Oehme et al., supra note 29 , at $86,87$.

118. Discover Policing, Types of Law Enforcement Agencies, http://discoverpolicing.org/whats_like/?fa=types_jobs (last visited Sept. 13, 2015).

119. Int'l Ass'n of Chiefs of Police, supra note 26.

120. Wash. Rev. Code AnN. § 10.99.090 (2006).

121. Id.

122. Id.

123. Id. 
124. Wilson \& Buckley, supra note 32; Los Angeles Police Dep't, Behavioral Science Services, http://www.lapdonline. org/inside_the_lapd/content_basic_view/6497 (last visited Sept. 13, 2015).

125. Wash. Rev. Code Ann. § 10.99.090 (2006); Wash. Rev. Code Ann. § 26.50 .150 (2010).

126. Wilson \& Buckley, supra note 32.

127. Id.

128. Borders, Benefits of Workplace Counseling, EmPLOYeE Counseling, http://www.employeecounselling.org/2010/09/ benefits-of-workplace-counselling/(last visited Sept. 13, 2015).

129. Id.

130. Wash. Rev. Code AnN. $§ 10.99 .090$ (2006).

131. Int'l Ass'n of Chiefs of Police, supra note 26.

132. Id.

133. Id.

134. Id.

135. Id.

136. Id.

137. Id.

138. Id.

139. Id.

140. Id.

141. Id.

142. Id.

143. Id.

144. Wash. Rev. Code AnN. § 10.99.090 (2006).

145. Id.

146. Id.

147. Id.

148. Id.

149. Id.

150. Id.

151. Id.

152. Joseph Goldstein, Officers, Exhorted to Report Corruption, Still fear Retaliation, N.Y. Times (June. 24, 2012), http:// www.nytimes.com/2012/06/25/nyregion/new-york-police-officers-face-retaliation-for-reporting-corruption.html?pagewanted=all\&_ $\mathrm{r}=0$.

153. Human Rights Watch, Code of Silence, available at http://www.hrw.org/legacy/reports98/police/uspo27.htm (last visited Sept. 13, 2015).

154. Ann Mullen, Breaking the Blue Code, Detroit Metro Times (Nov. 8, 2000), http://www.metrotimes.com/detroit/ breaking-the-blue-code/Content?oid=2169881.

155. Id; Goldstein, supra note 152; Human Rights Watch, supra note 153; Brian Flood, Police corruption due to "blue code of silence," UIC NEws CENTER (Jan. 22, 2013), http://news.uic.edu/police-corruption-enabled-by-blue-code-of-silence.

156. Mullen, supra note 154 .

157. Id.

158. Id.

159. Oehme et al., supra note 29 , at 89.

160. Ben Winslow, Police Chiefs Could Face Punishment for Not Reporting Officer Misconduct, Fox 13 Salt LaKe City (Jan. 6, 2015), http://fox13now.com/2015/01/06/police-chiefs-could-face-punishment-for-not-reporting-officer-misconduct/; Naomi Martin, 2 Dallas Officers File Whistleblower Suit Claiming Retaiation for Reporting Misconduct, DALLAS MoRNING News (Oct. 8, 2015), http://crimeblog.dallasnews.com/2015/10/2-dallas-officers-file-whistleblower-suit-claiming-retaliationfor-reporting-misconduct.html/; Goldstein, supra note 150.

161. Goldstein, supra note 152.

162. Wash. Rev. Code AnN. § 10.99 .090 (2006).

163. Fagan, supra note 19.

164. Wash. Rev. Code Ann. $\$ 10.99 .090$ (2006).

165. Barton, supra note 22.

166. Mulick, supra note 23; 42 U.S.C.A. § 3796gg (2013).

167. Jack Rinehart, Survey: 25 percent of domestic violence victims would not report abuse to police, INDY CHANNEL (Oct. 9, 2015), http://www.theindychannel.com/news/local-news/survey-25-percent-of-domestic-violence-victims-dont-reportabuse-to-police; Nat'l Domestic Violence Hotline, Who Will Help Me? Domestic Violence Survivors Speak Out About Law Enforcement Response (2015), http://www.thehotline.org/resources/law-enforcement-responses.

168. Id.

169. Eugene Volokh, Call the Police Because Your Husband is Beating You, Lose Millions of Dollars, WASH. Post (Sept. 12, 2014), http://www.washingtonpost.com/news/volokh-conspiracy/wp/2014/09/12/call-the-police-because-your-husband-isbeating-you-lose-millions-of-dollars/. 
170. Volokh, supra note 169.

171. Id.

172. Cohen et al., supra note 17.

173. Volokh, supra note 169.

174. Id.

175. Stacy Bannerman, High Risk of Military Domestic Violence On The Front, S.F. Gate (April. 7, 2014), http://www. sfgate.com/opinion/article/High-risk-of-military-domestic-violence-on-the-5377562.php; Katie J.M. Baker, Domestic Violence On Campuses Is The Next Big College Controversy, BuzzFeEd (June. 9, 2015), http://www.buzzfeed.com/katiejmbaker/domesticviolence-is-the-next-big-college-civil-rights-battl\#.tnGB7KX45w

176. Tony Dokoupil, Why Domestic Violence Prevention Programs Don't Work, NBC News (Oct. 4, 2014), http://www. nbcnews.com/storyline/nfl-controversy/why-domestic-violence-prevention-programs-dont-work-n217346.

177. Id.

Rafaqat Cheema is a graduating law student at Maurice A. Dean School of Law at Hofstra University. He graduated from CUNY College of Staten Island with a bachelor's degree in history. In his final year he served as the Page Proof Editor for Family Court Review. Additionally, in his final semester he interned at the Disaster Recovery Law Clinic, working with Superstorm Sandy victims. He would like to thank his family, especially his mother, for all the support. 